University of Nebraska - Lincoln

DigitalCommons@University of Nebraska - Lincoln

\title{
Using Electrical Conductivity Classification and Within-Field Variability to Design Field-Scale Research
}

\author{
Cinthia K. Johnson \\ USDA-ARS, cjohnso2@bigred.unl.edu \\ Kent M. Eskridge \\ USDA-ARS, keskridge1@unl.edu \\ Brian J. Wienhold \\ University of Nebraska-Lincoln, Brian.Wienhold@ars.usda.gov \\ John W. Doran \\ University of Nebraska-Lincoln, jdoran1@unl.edu \\ Gary A. Peterson \\ USDA-ARS, gary.peterson@colostate.edu \\ See next page for additional authors
}

Follow this and additional works at: https://digitalcommons.unl.edu/usdaarsfacpub

Johnson, Cinthia K.; Eskridge, Kent M.; Wienhold, Brian J.; Doran, John W.; Peterson, Gary A.; and Buchleiter, Gerald W., "Using Electrical Conductivity Classification and Within-Field Variability to Design Field-Scale Research" (2003). Publications from USDA-ARS / UNL Faculty. 1185.

https://digitalcommons.unl.edu/usdaarsfacpub/1185

This Article is brought to you for free and open access by the U.S. Department of Agriculture: Agricultural Research Service, Lincoln, Nebraska at DigitalCommons@University of Nebraska - Lincoln. It has been accepted for inclusion in Publications from USDA-ARS / UNL Faculty by an authorized administrator of DigitalCommons@University of Nebraska - Lincoln. 


\section{Authors}

Cinthia K. Johnson, Kent M. Eskridge, Brian J. Wienhold, John W. Doran, Gary A. Peterson, and Gerald W. Buchleiter 


\title{
PRECISION MAPPING
}

\section{Using Electrical Conductivity Classification and Within-Field Variability to Design Field-Scale Research}

\author{
Cinthia K. Johnson,* Kent M. Eskridge, Brian J. Wienhold, John W. Doran, \\ Gary A. Peterson, and Gerald W. Buchleiter
}

\begin{abstract}
Agronomic researchers are increasingly accountable for research programs and outcomes relevant to producers. Participatory research-where farmers assume leadership roles in identifying, designing, and managing on-farm field-scale research-addresses this directive. However, replication is often unfeasible at this level of scale, underscoring a need for alternative methods to estimate experimental error. We compared mean square errors to evaluate: (i) within-field variability for estimating experimental error (in lieu of replication) and (ii) classified within-field variability, using apparent electrical conductivity $\left(\mathbf{E C}_{\mathrm{a}}\right)$, for estimating plot-scale experimental error. Eight 31-ha fields, within a contiguous section of farmland ( $250 \mathrm{ha})$, were managed as two replicates of each phase of a no-till winter wheat (Triticum aestivum L.)-corn (Zea mays L.)-millet (Panicum miliaceum L.)-fallow rotation. The section was $\mathbf{E C}_{\mathrm{a}}$-mapped (approximately 0 - to $30-\mathrm{cm}$ depth) and separated into four classes (ranges of $\left.\mathbf{E C}_{\mathrm{a}}\right)$. Georeferenced sites $(n=96)$ were selected within classes, sampled, and assayed for multiple soil parameters (0- to 7.5- and 0- to 30-cm depths) and residue mass. Within-field variance effectively estimated experimental error variance for several evaluated parameters, supporting its potential application as a surrogate for replication. Comparison of data from the field-scale experimental site to that from a nearby plot-scale experiment revealed that $\mathrm{EC}_{\mathrm{a}}$-classified withinfield variance approximates plot-scale experimental error. We propose using this relationship for a systems approach to research wherein treatment differences and their standard errors, derived from $\mathbf{E C}_{\mathbf{a}}-$ classified field-scale experiments, are used to roughly evaluate treatments and identify research questions for further study at the plot scale.
\end{abstract}

\begin{abstract}
A Gronomic researchers are typically required to conduct research programs that produce information relevant to producers. "Applied research by definition, must be designed to provide useful information rather than to discover general truths" (Ikerd, 1993). To this end, growing numbers of researchers and farmers are advocating participatory research where farmers contribute to long-term research agendas and assume leadership roles in the identification, design, and management of on-farm research programs (Norman et al.,

C.K. Johnson, B.J. Wienhold, and J.W. Doran, USDA-ARS, 119 Keim Hall, Lincoln, NE 68583-0934; K.M. Eskridge, Univ. of Nebraska, 103 Miller Hall, Lincoln, NE 68583; G.A. Peterson, Colorado State Univ., C130 Plant Sci., Ft. Collins, CO 80523; and G. Buchleiter, USDAARS, AERC-CSU, Ft. Collins, CO 80523-1325. The USDA-ARS Northern Plains Area is an equal opportunity/affirmative action employer, and all agency services are available without discrimination. Received 14 Feb. 2002.*Corresponding author (cjohnso2@bigred. unl.edu).
\end{abstract}

Published in Agron. J. 95:602-613 (2003).
1998; Ikerd, 1993; Gerber, 1992; Rzewnicki, 1991; Watkins, 1990). Many national and university research groups have implemented this research philosophy in the form of farmer-comprised focus groups that function in an advisory capacity. These associations have resulted in increased on-farm experimentation.

Some types of research, or research goals, require the precision achievable only through controlled plot-scale experimentation; other research goals are well suited to on-farm investigations. Experiments best conducted on farm include those (i) requiring specific soil types or environmental conditions not found on an experiment station, (ii) involving the study of farm management, (iii) analyzing integrated systems such as crop and livestock production, (iv) evaluating performance of a management system under real farm conditions, (v) examining occurrences requiring large land areas (e.g., runoff, erosion, and pest infestation), (vi) studying the longterm effects of specific management practices, and (vii) evaluating farmer innovations (Lockeretz, 1987). Many of these examples require field-scale analyses. New technologies used in site-specific management and other sustainable management practices, including global positioning systems, geographic information systems, and field-scale sensors, are also best evaluated at the field scale (Vanden Heuvel, 1996).

Field-scale research addresses issues of operational scale and soil variability to produce outcomes different from those of experiment station-based research (Table 1). It promotes broad-based investigations that address not only technical, but also economic and social factors; increases farmer involvement, interest, acceptance, and adoption of successful outcomes; and facilitates a systems perspective, wherein multiple components are evaluated. It has been suggested that farmervested field-scale research can reverse research direction and emphasis (Sumberg and Okali, 1988). Instead of functioning merely as a means to validate experiment station findings, these experiments allow us to begin with the system. Research questions that originate from system outcomes can then be investigated using the more sensitive experiment station plot-scale approach.

Although on-farm field-scale research offers exciting possibilities for appropriate and influential investigations, it does not always lend itself the traditional design

Abbreviations: EC, electrical conductivity; $\mathrm{EC}_{\mathrm{a}}$, apparent electrical conductivity; FICS, Farm-Scale Intensive Cropping Study; MS, mean square; OM, organic matter; SDAMP, Sustainable Dryland Agroecosystem Management Project. 
Table 1. Some differences between station-based and farm-systems research (after Norman et al., 1995).

\begin{tabular}{|c|c|c|}
\hline Characteristic & Station-based research & Farm-systems research \\
\hline Location of Trial & Experiment station & On-farm \\
\hline Disciplines involved & $\begin{array}{l}\text { Often single } \\
\text { Mostly technical }\end{array}$ & $\begin{array}{l}\text { Usually several } \\
\text { Technical and social }\end{array}$ \\
\hline \multicolumn{3}{|l|}{ Priority setting for trial } \\
\hline Researcher & More involved & Less involved \\
\hline Farmer & Less involved & More involved \\
\hline \multicolumn{3}{|l|}{ Experimental design } \\
\hline Complexity & Usually more & Usually less \\
\hline Management & Researcher & Researcher or farmer \\
\hline Implementation & Researcher & Researcher or farmer \\
\hline Degree of experimental control & More & Usually less \\
\hline \multirow{2}{*}{\multicolumn{3}{|c|}{ Evaluation of trial results: }} \\
\hline & & \\
\hline Systems perspective & Less likely & More likely \\
\hline Technical feasibility & Yes & Yes \\
\hline Economic feasibility & Less likely & More likely \\
\hline Social acceptability & Less likely & More likely \\
\hline Farmer opinion & Not likely & More likely \\
\hline \multicolumn{3}{|l|}{ Expense of experimental program } \\
\hline Fixed (overhead) costs & Likely to be higher & Likely to be lower \\
\hline Variable (recurrent) costs & Likely to be lower & Likely to be higher \\
\hline $\begin{array}{l}\text { Farmer adoption of evaluated technology } \\
\text { found to be successful or appropriate }\end{array}$ & Likely to be slower & Likely to be more rapid \\
\hline
\end{tabular}

concepts of replication and blocking. Replication is defined as multiple experimental units per treatment where an experimental unit is the smallest subdivision of experimental material to which a treatment is independently applied (Lentner and Bishop, 1993). Blocking is the grouping of experimental units within a homogeneous area where typically each treatment is randomly assigned to no more than one experimental unit in a block. In field-scale research, the experimental unit is usually a field. Given the expanse of land generally comprising a field, replication is often difficult or even impossible (Carpenter, 1990). If the results of field-scale research are to be accepted as scientifically valid, new ways must be identified to obtain reasonable estimates of experimental error in lieu of replication.

Precedent exists for unreplicated experiments, particularly within the specific research disciplines of engineering, plant breeding, and landscape ecology. Examples of nonreplicated experiments take several forms. Multiple locations of identical treatments (Moreau et al., 1999; Johnson et al., 1992) are commonly used as replicates. Time-series experimental designs compare changes in treatment units with those of a reference unit over time (Hawkins, 1986; Stewart-Oaten et al., 1986). Before-and-after comparisons are used in environmental impact studies (Wiens and Parker, 1995). Multiple independent experimental results are sometimes combined to simulate replication (Hannah, 1999). Other researchers have used preliminary or separate tests to derive an estimate of experimental error that is applied in subsequent experiments, making experimental error derived from replication unnecessary (Sahagün-Castellanos and Frey, 1994; Box et al., 1978, p. 374418). Beyers (1998) suggested the use of causal inference supported by simple descriptive statistics, including tables, graphs, estimates of means and standard errors, regression, and multivariate analyses to evaluate experimental results.

Although a plethora of analyses and design approaches exist for nonreplicated experiments, clear and widely accepted solutions to this problem are lacking (Stewart-Oaten et al., 1992). This is because the omission of replication in experimental design can have serious repercussions. Conclusions stemming from nonreplicated experiments may be transferable to only a small population of experimental units, sometimes to only the original experimental area. Assumed hypotheses may not be those actually tested, the degree of precision may be overestimated, perceived treatment differences may merely reflect variation among experimental units rather than treatments, and the effects of treatments and experimental units may be confounded. Statistical designs not incorporating replication must address these issues.

Increasingly, agronomic investigators are exploring the use of computer and satellite technologies applied as field-scale tools, including georeferenced crop yield monitors, remotely sensed data, and $\mathrm{EC}_{\mathrm{a}}$ sensors. This technology is appropriate to a broad-based and largescale approach to agricultural experimentation that focuses on spatial patterns across a field. As a result, much current agronomic research is directed toward understanding temporal and spatial interrelationships among physical, chemical, and biological soil properties and their combined contributions to crop productivity at the field scale.

Soil clay type and percentage, moisture (in conjunction with pore size, tortuosity, and water-filled pore space as they vary with depth), salinity of the soil solution, and temperature can affect $\mathrm{EC}_{\mathrm{a}}$ measurement (Rhoades et al., 1989; McNeill, 1980). One or more of these factors will dominate $\mathrm{EC}_{\mathrm{a}}$ in specific soils. Significant correlations have been documented between $\mathrm{EC}_{\mathrm{a}}$ and soil properties affecting its measurement, including soil moisture (Khakural et al., 1998; Sheets and Hendrickx, 1995), salinity (Lesch et al., 1992; Rhoades and Corwin, 1981), and depth to claypan (Sudduth et al., 1995).

Previous experiments at a semiarid experimental site, the Farm-Scale Intensive Cropping Study (FICS) (Johnson et al., 2001), revealed that soil properties (0- to 
7.5- and/or 0- to 30-cm depths) associated with erosion [percentage clay, bulk density, $\mathrm{pH}$, and laboratorymeasured electrical conductivity (EC)] were positively correlated with $\mathrm{EC}_{\mathrm{a}}$ (approximately $0-30 \mathrm{~cm}$ depth of measurement) while soil properties indicative of crop productivity [soil moisture, total and particulate organic matter (OM), total $\mathrm{C}$ and $\mathrm{N}$, extractable $\mathrm{P}$, microbial biomass $\mathrm{C}$ and $\mathrm{N}$, and potentially mineralizable $\mathrm{N}$ ] were negatively correlated with $\mathrm{EC}_{\mathrm{a}}$ (Table 2). Some of these soil properties are directly measured by $\mathrm{EC}_{\mathrm{a}}$ while others are correlated with them. Variable levels of individual soil parameters can be associated with a single $\mathrm{EC}_{\mathrm{a}}$ value because of the buffering effect of corresponding variations in opposing soil parameters affecting $\mathrm{EC}_{\mathrm{a}}$. For this reason, at the FICS site, $\mathrm{EC}_{\mathrm{a}}$ appears to be most useful as a tool for integrating the multiple soil physical, chemical, and biological properties that underlie production potential.

Following classification of the FICS into zones based on ranges of $\mathrm{EC}_{\mathrm{a}}$, all above-mentioned physical, chemical, and biological soil properties (0- to 7.5- and/or 0- to 30 -cm depths) and surface residue content were different among $\mathrm{EC}_{\mathrm{a}}$ classes $(P \leq 0.06)$. The effectiveness of $\mathrm{EC}_{\mathrm{a}}$ for delineating yield potential at the FICS was corroborated by strong relationships $(r=-0.97$ to $-0.99)$ between mean $\mathrm{EC}_{\mathrm{a}}(0-30 \mathrm{~cm}$ depth of measurement) within $\mathrm{EC}_{\mathrm{a}}$ class and mean yields within $\mathrm{EC}_{\mathrm{a}}$ class for winter wheat in both typical- and high-yielding years (Johnson et al., 2003). Similar correlations with $\mathrm{EC}_{\mathrm{a}}$ were found for both winter wheat and corn yields when $\mathrm{EC}_{\mathrm{a}}$ was measured at deeper depths $(0-90 \mathrm{~cm})$.

In published reports, the relationship between $\mathrm{EC}_{\mathrm{a}}$ and yield is often significant within crop treatments and fields but inconsistent across years (Jaynes et al., 1993; Sudduth et al., 1995; Kitchen et al., 1999). These studies have been conducted in humid, high-precipitation re-

Table 2. Correlation $(r \times 100)$ between apparent electrical conductivity $\left(\mathrm{EC}_{\mathrm{a}}\right)$, measured at approximately 0 - to $30-\mathrm{cm}$ depth, and soil attributes sampled at 0 - to 7.5 - and $0-$ to $30-\mathrm{cm}$ depths $(n=96)$.

\begin{tabular}{|c|c|c|}
\hline \multirow[b]{2}{*}{ Soil attribute } & \multicolumn{2}{|c|}{ Depth of soil sample } \\
\hline & $0-7.5 \mathrm{~cm}$ & 0-30 cm \\
\hline & \multicolumn{2}{|c|}{ - Correlation with $\mathbf{E C}_{\mathrm{a}}-$} \\
\hline Physical properties & & \\
\hline Bulk density & $\mathbf{5 0} * * *$ & $49 * * * *$ \\
\hline Silt & $-\mathbf{3 5} * * *$ & $-28 * *$ \\
\hline Clay & $36 * * *$ & $\mathbf{5 0} * * *$ \\
\hline Water content & $-\mathbf{5 0} * * *$ & $-33 * * *$ \\
\hline \multicolumn{3}{|l|}{ Chemical properties } \\
\hline Laboratory EC & 19 & $44 * * *$ \\
\hline pH & 15 & $37 * * *$ \\
\hline $\mathbf{P}$ & $-\mathbf{5 8}^{* * *} *$ & $-58 * * *$ \\
\hline Total OM $\dagger$ & $-\mathbf{3 4} * * *$ & $-34 * * *$ \\
\hline Particulate OM (0.05-0.5 mm) & $-31^{* *}$ & -13 \\
\hline Particulate OM (0.5-2 mm) & $-\mathbf{2 0} *$ & $-25 * *$ \\
\hline Total C & $-42 * * * *$ & $-36 * * *$ \\
\hline Total N & $-36 * * *$ & $-38 * * *$ \\
\hline \multicolumn{3}{|l|}{ Biological properties } \\
\hline Microbial biomass $\mathbf{C}$ & $-33^{* *}$ & -26 \\
\hline Microbial biomass $\mathbf{N}$ & $-37 * * *$ & -2 \\
\hline Potentially mineralizable $\mathrm{NH}_{4}-\mathrm{N}$ & $-53 * * *$ & $-\mathbf{5 0} * * *$ \\
\hline $\begin{array}{l}* \text { Significant at the } 0.05 \text { probability } \\
* * \text { Significant at the } 0.01 \text { probability } \\
* * * \text { Significant at the } 0.001 \text { probabil }\end{array}$ & & \\
\hline
\end{tabular}

gions where yields are limited by both insufficient and excessive precipitation. In these regions, variable precipitation inputs can alter or even reverse the relationship between the soil properties driving $\mathrm{EC}_{\mathrm{a}}$ and crop yields. In semiarid cropping systems such as the FICS, where yields typically reflect only the degree of drought stress, $\mathrm{EC}_{\mathrm{a}}$ may more consistently predict yield.

It is important to note that while the magnitude of measured $\mathrm{EC}_{\mathrm{a}}$ fluctuates over time, spatial patterns or zones of $\mathrm{EC}_{\mathrm{a}}$ remain constant (Lund et al., 1999; Sudduth et al., 2001). The ability to map patterns of productivity across a landscape makes possible novel research opportunities. Zones of within-field variability based on ranges of $\mathrm{EC}_{\mathrm{a}}$ may be applicable to the statistical evaluation of treatment effects in field-scale experiments. It may be possible to estimate experimental error based on within-field observations instead of replication through random sampling across a field or by using new technologies, such as $\mathrm{EC}_{\mathrm{a}}$ classification. In soils where $\mathrm{EC}_{\mathrm{a}}$-classified zones explain a significant amount of the variability in production potential within a field, zonebased sampling schemes may reduce error variance compared with samples taken at random. It is also possible that the variances of field measurements taken within $\mathrm{EC}_{\mathrm{a}}$ zones may provide an estimate of small-plot experimental error. This assumes a traditional plot-scale randomized complete block design established within the experimental site where the $\mathrm{EC}_{\mathrm{a}}$ zones function as blocks.

The dilemma presented by the lack of feasible replication and blocking in field-scale research is the focus of this paper. We examined the relationships among fieldscale within-field variability, field-scale replication, and plot-scale blocking and the implications of these relationships for statistically evaluating field-scale experiments. Our primary objective was to determine whether field-scale experimental error can be estimated using within-field variability in soil condition; if this is feasible, traditional replication may be unnecessary. A secondary objective was to evaluate $\mathrm{EC}_{\mathrm{a}}$ classification as a basis for estimating plot-scale experimental error. This may permit the screening of treatments and treatment effects at the field scale for further investigation in plot-scale work.

\section{MATERIALS AND METHODS}

\section{Site}

These analyses were conducted as part of the FICS, a new long-term experiment comprised of 250 ha of farmland located $30 \mathrm{~km}$ east of Sterling, CO. The site was cultivated since the early 1930 s using a traditional 2 -yr rotation of winter wheatfallow. Weeds were controlled during the fallow year using a moldboard plow or a heavy offset disk initially, followed by one operation with a chisel plow and four to six operations with a rod weeder. In 1999, a study was initiated to examine the economic and ecological implications of conversion from wheat-fallow conventional tillage to an intensified 4-yr rotation of winter wheat-corn-proso millet-fallow under no-tillage management. In plot-scale research, no-till-intensified cropping management has been shown to conserve both soil water and C (Bowman et al., 1998; Peterson et al., 1998, 1996). 


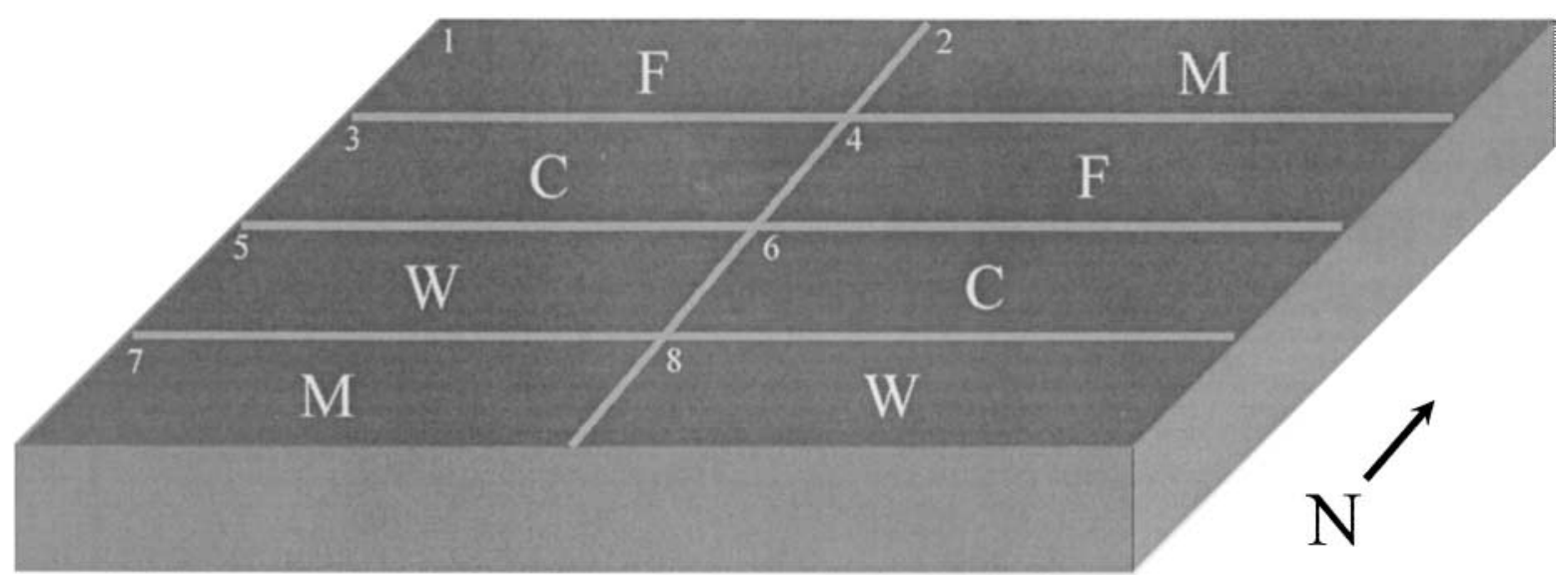

Fig. 1. Experimental layout for 1999. The 250-ha experimental site is subdivided into eight approximately 31-ha fields. Two replicates of each phase of the winter wheat $(\mathrm{W})$, corn $(\mathrm{C})$, proso millet $(\mathrm{M})$, and fallow (F) rotation are represented each year. The entire site is managed under no-tillage.

The FICS site is managed as eight approximately 31-ha fields to include two replicates of each phase of the 4-yr rotation each year (Fig. 1). It is gently sloping (0-5\%) and comprised of a mixture of soils, including Platner (fine, smectitic, mesic Aridic Paleustolls), Weld (fine, smectitic, mesic Aridic Argiustolls), and Rago loam (fine, smectitic, mesic Pachic Argiustolls). Regional climate is cool and semiarid with a mean annual temperature of $10^{\circ} \mathrm{C}$ and mean annual precipitation of $420 \mathrm{~mm}$. Precipitation is highly variable, with $75 \%$ falling between April and September, and highest amounts in May, June, and July.

\section{Experimental Approach}

In March of 1999, a Veris 3100 Sensor Cart (Veris Technol., a division of Geoprobe Syst., Salina, KS $)^{1}$ was used to produce individual georeferenced $\mathrm{EC}_{\mathrm{a}}$ maps for each of the eight fields in the study. The instrument was pulled behind a pickup truck (15-m swath width at $4.5 \mathrm{~m} \mathrm{~s}^{-1}$ ) while recording $\mathrm{EC}_{\mathrm{a}}$ data at 1 -s intervals to total approximately 33000 data points for the entire study site. A Trimble AG132 D global positioning system (Trimble Navigation Limited., Sunnyvale, CA) ${ }^{1}$, with submeter accuracy, and the Veris 3100 Sensor Cart were connected to a Veris data logger. This instrument recorded latitude, longitude, and shallow $(0-30 \mathrm{~cm})$ and deep $(0-90 \mathrm{~cm})$ $\mathrm{EC}_{\mathrm{a}}\left(\mathrm{mS} \mathrm{m}^{-1}\right)$ in an ASCII text format. Because of long-term experimental objectives to track changes in soil characteristics associated with management, only shallow data $(0-30 \mathrm{~cm})$ were used in the current study. For reporting purposes, $\mathrm{EC}_{\mathrm{a}}$ was converted to $\mathrm{dS} \mathrm{m}^{-1}$.

A stratified soil-sampling strategy was developed wherein strata were allocated into four classes based on ranges in $\mathrm{EC}_{\mathrm{a}}$. Using ERDAS Imagine (ERDAS, Atlanta, GA), EC $\mathrm{C}_{\mathrm{a}}$ maps from each of the eight fields in the study site were individually interpolated by inverse-distance weighting. Next, $\mathrm{EC}_{\mathrm{a}}$ data in each interpolated map was spatially clustered using unsupervised classification (ERDAS, 1997) to form 12 classes of $E_{a}$ (10- $\mathrm{m}^{2}$ grid-cell resolution), which were then recoded (combined) into four classes. Recoding was done by adjusting within-class $\mathrm{EC}_{\mathrm{a}}$ ranges to mimic the dominant visible spatial patterns observed in the original 12-class gray-scale $\mathrm{EC}_{\mathrm{a}}$ maps

\footnotetext{
${ }^{1}$ Mention of a trademark, proprietary product, or vendor does not constitute an guarantee of or warranty of the product by USDA nor imply its approval to the exclusion of other products that may be suitable.
}

(Fig. 2). This classification procedure aggregates $\mathrm{EC}_{\mathrm{a}}$ data points into naturally occurring clusters to minimize withinclass variance.

Across-field ranges of $\mathrm{EC}_{\mathrm{a}}\left(\mathrm{dS} \mathrm{m}^{-1}\right)$ were 0.00 to 0.17 (low $\mathrm{EC}_{\mathrm{a}}$ class), 0.12 to 0.23 (medium-low $\mathrm{EC}_{\mathrm{a}}$ class), 0.14 to 0.29 (medium-high $\mathrm{EC}_{\mathrm{a}}$ class), and 0.18 to 0.78 (high $\mathrm{EC}_{\mathrm{a}}$ class). Twelve georeferenced soil-sampling sites were identified in each of the eight fields, three per $\mathrm{EC}_{\mathrm{a}}$ class (Fig. 2) to total 96 sites across the experiment. To effectively evaluate $\mathrm{EC}_{\mathrm{a}}$ classification, sampling sites were selected to avoid betweenclass transition zones; for this reason, sites were centrally positioned within large, nonadjoining areas comprising each of the four $\mathrm{EC}_{\mathrm{a}}$ classes. Sites were also selected to provide comprehensive coverage of each field.

\section{Soil Sampling and Analysis}

The experimental site was sampled in two phases based on crop status. Wheat and fallow fields were sampled in midAugust 1999 following wheat harvest while millet and corn fields were sampled in mid-November 1999 following corn harvest. At each of the 96 sampling points, seven 4-cm-diam. soil cores were taken at 0 - to 7.5- and 7.5- to 30-cm depths, composited by depth and mixed well. Surface soils $(0-7.5 \mathrm{~cm}$ depth) were sieved to pass a $2-\mathrm{mm}$ screen. At this point, a portion of the soil was stored at $4^{\circ} \mathrm{C}$ while the remainder was air-dried. Due to their higher water content, deeper soils $(7.5-30 \mathrm{~cm})$ were sieved to $4 \mathrm{~mm}$. Once again, a portion of the soil was stored at $4^{\circ} \mathrm{C}$. The remainder was air-dried and ground through a soil grinder (M.G. Johnston Industries, Lakeville, MN $)^{1}$ to pass a 2 -mm sieve. This type of grinder crushes soils to leave residues intact for particulate $\mathrm{OM}$ analyses.

Soil was assessed using physical, chemical, and biological parameters as proposed by Doran and Parkin (1996). Soil physical parameters included bulk density (Blake and Hartge, 1986), texture (Kettler et al., 2001), and gravimetric water content. Chemical measurements consisted of total and particulate OM (0.053- to 0.5 - and 0.5 - to $2-\mathrm{mm}$ size fractions) by loss on ignition (Cambardella et al., 2000); $\mathrm{pH}$ and laboratorymeasured EC, using a 1:1 water/soil mixture; $2 \mathrm{M} \mathrm{KCl}-$ extracted $\mathrm{NO}_{3}-\mathrm{N}$ and $\mathrm{NH}_{4}-\mathrm{N}$, measured on a LACHAT FIA autoanalyzer (Zellweger Analytics, LACHAT Instrument Div., Milwaukee, WI); total C and N, analyzed with a Carlo Erba NA 100 (CE Elantech, Lakewood, NJ); and extractable P, by the Bray-1 method (Bray and Kurtz, 1945). Microbial 
biomass C and N, by microwave irradiation (Islam et al., 1998), and anaerobically incubated potentially mineralizable $\mathrm{N}$ (Waring and Bremmer, 1964; Keeney, 1982) analyses were conducted to assess soil biological function. All testing was performed on air-dried soil with the exception of microbial biomass $\mathrm{C}$ and $\mathrm{N}, \mathrm{pH}$, laboratory-measured $\mathrm{EC}$, and anaerobic potentially mineralizable $\mathrm{N}$, which were assayed using fresh soil within 2 wk of collection.

\section{Statistical Analyses}

The data in this study were analyzed as a complete block with two blocks (or replicates) and four rotational phases that functioned as treatments within each block. When the study was initiated in 1999, treatments were assigned to each of the eight fields to maintain continuity between historical and newly imposed treatments (Fig. 1). Electrical conductivity class was used as an additional blocking variable (Table 3 ). All data were analyzed on a volumetric basis with the exception of $\mathrm{KCl}$-extracted $\mathrm{NO}_{3}-\mathrm{N}$ and $\mathrm{NH}_{4}-\mathrm{N}\left(\mu \mathrm{g} \mathrm{g}{ }^{-1}\right.$ soil) and water content ( $\mathrm{g} \mathrm{g}^{-1}$ soil). Although soil samples were collected and analyzed using 0 - to 7.5 - and 7.5- to $30-\mathrm{cm}$ soil depths, statistical comparisons were made on $0-$ to $7.5-$ and $0-$ to $30-\mathrm{cm}$ depth increments. Data from the two analyzed depths were combined and weighted to calculate $0-$ to $30-\mathrm{cm}$ values that best corresponded to the depth of $\mathrm{EC}_{\mathrm{a}}$ measurement $(0-30 \mathrm{~cm})$.
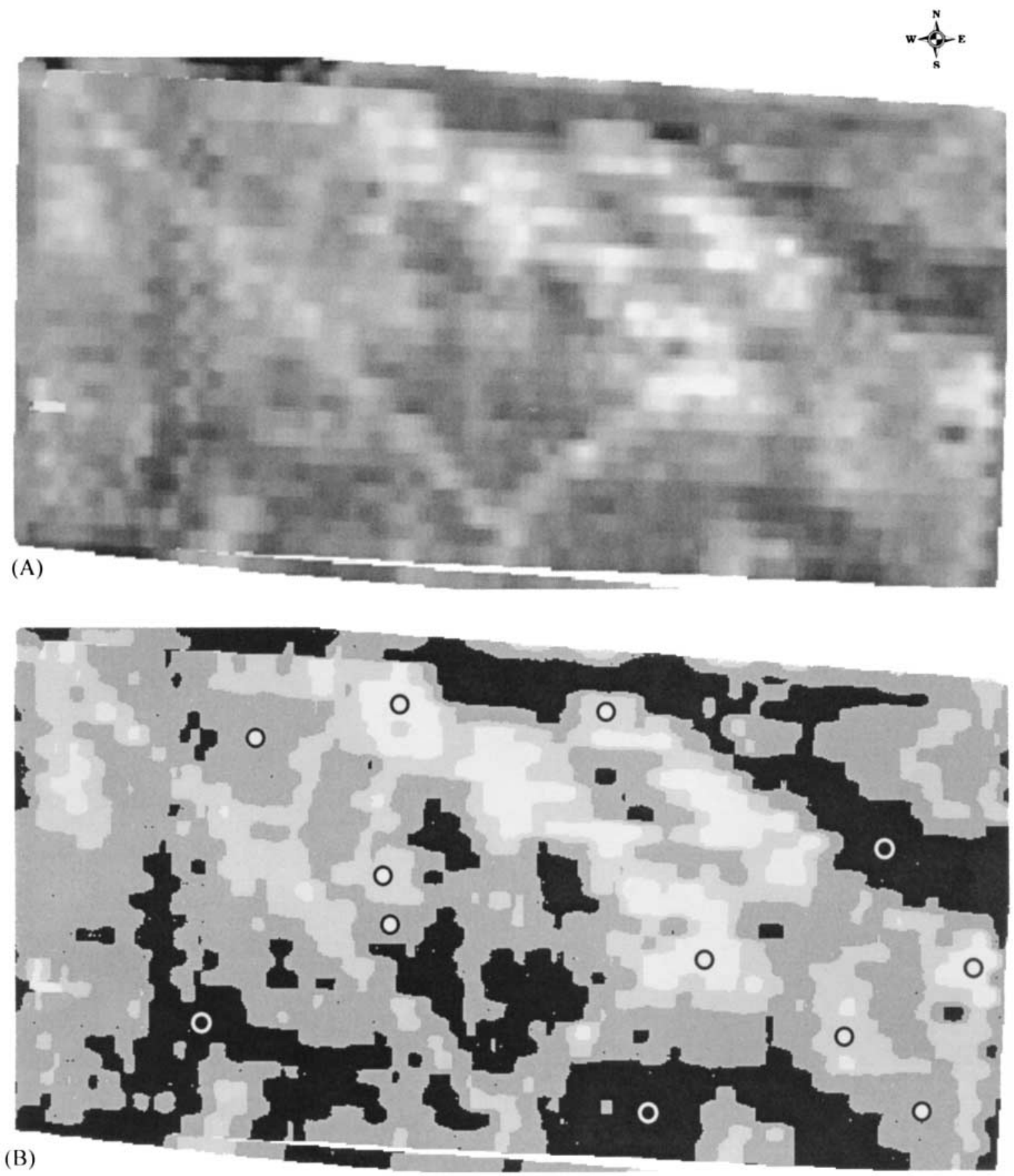

Fig. 2. An interpolated and classified electrical conductivity map (12 classes determined by unsupervised classification) for the field located in (A) the northwest corner of the experimental site and (B) the same map following recoding into four electrical conductivity classes. Variations in color, from dark to light, correspond to increasing conductivity, and the $\bigcirc$ symbols represent selected soil-sampling sites. Ranges of apparent electrical conductivity for each of the four classes from low to high are 0 to $0.17,0.17$ to $0.23,0.23$ to 0.29 , and 0.29 to $0.56 \mathrm{dS}^{-1}$. 
A sequential statistical approach was used to compare experimental error using replication to that derived from $\mathrm{EC}_{\mathrm{a}}-$ classified within-field variability. First, the within-field mean square (MS), $\mathrm{EC}_{\mathrm{a}}$ block + error (88 df), was compared with the MS (rep $\times$ crop) (Table 3$)$. In classic randomized complete block analysis, MS (rep $\times$ crop) estimates experimental error. For each soil parameter, we tested to determine if the MS (rep $\times$ crop) was significantly larger than MS (within field), with nonsignificance indicating that MS (within field) might be a reasonable estimate of experimental-error variability. However, the MS (rep $\times$ crop) could be significantly larger than the MS (within field) due to nonadditivity. Nonadditivity occurs when blocks (or replicates) significantly interact with crops, resulting in the overestimation of experimental error by the MS (rep $\times$ crop). This elicits the incorrect conclusion that within-field variability is smaller than experimental error.

If nonadditivity was significant for an individual soil property, a second step was taken in the analysis. Nonadditivity effects in the rep $\times$ crop term were removed, and the residual MS was applied for an improved estimate of experimental error (Tukey, 1949; Lentner and Bishop, 1993). We then tested to determine if the residual MS was significantly larger than the MS (within field). The MS (within field) was considered to be a reasonable estimate of experimental error for a given soil parameter if this $F$ test was not significant.

Small-plot experiments are typically conducted as randomized complete block designs where plots are grouped into blocks based on soil properties. Assuming $\mathrm{EC}_{\mathrm{a}}$ classifications are reasonable surrogates for blocks, a small-plot randomized complete block design might be set out as in Fig. 3C. In this case, experimental error for the small-plot experiment could be estimated by the variability among sampling points in each $\mathrm{EC}_{\mathrm{a}}$ classification as obtained by the MS error (64 df) in Table 3.

To evaluate the use of $\mathrm{EC}_{\mathrm{a}}$-classified within-field variability as an estimate of small-plot experimental error, we compared
Table 3. Partitioned skeleton ANOVA for the experimental treatment design used in the Farm-Scale Intensive Cropping Study near Sterling, CO.

\begin{tabular}{|c|c|}
\hline Source & Degrees of freedom \\
\hline Replicate & 1 \\
\hline Crop & 3 \\
\hline Replicate $\times$ crop & 3 \\
\hline Nonadditivity & 1 \\
\hline Residual & 2 \\
\hline $\mathbf{E C}_{\mathrm{a}} \dagger$ class $($ rep $\times$ crop $)$ & 24 \\
\hline $\mathbf{E C}_{\mathrm{a}}$ class & 3 \\
\hline $\mathbf{E C}_{\mathrm{a}}$ class $\times$ rep & 3 \\
\hline $\mathbf{E C}_{\mathrm{a}}$ class $\times$ crop & 9 \\
\hline $\mathbf{E C}_{\mathrm{a}}$ class $\times$ rep $\times$ crop & 9 \\
\hline Error & 64 \\
\hline Total & 95 \\
\hline
\end{tabular}

$\dagger \mathbf{E C}_{\mathbf{a}}$, apparent electrical conductivity.

the MS errors of several soil parameters and surface residue mass (preplant and postharvest) from our study with those of previously collected data from a plot-scale experimental site located approximately $13 \mathrm{~km}$ south. This site is part of the Sustainable Dryland Agroecosystem Management Project (SDAMP) initiated in 1986 (Peterson et al., 1993). It is organized as a split-split block design with location, topography, crop rotation, fertilizer, and time variables.

Soil and residue data collected from the SDAMP site were used for comparison with those of the FICS. Soil data included total $\mathrm{C}$ and $\mathrm{N}$ concentration, analyzed on a Leco analyzer (Leco Corp., St. Joseph, MI) ${ }^{1}$; pH, using a 1:2 water/soil mixture; $\mathrm{P}$, analyzed by the $\mathrm{NaHCO}_{3}$ method (Olsen and Dean, 1965); and bulk density. With the exception of bulk density, all soil data from this site were analyzed as a complete block design with two blocks (or replicates), 10 rotational phases (treatments) within each block, three slope gradient classes, and 8 to 12 yr (determined by available data) as a time variable. Residue comparisons were made in the same manner, except

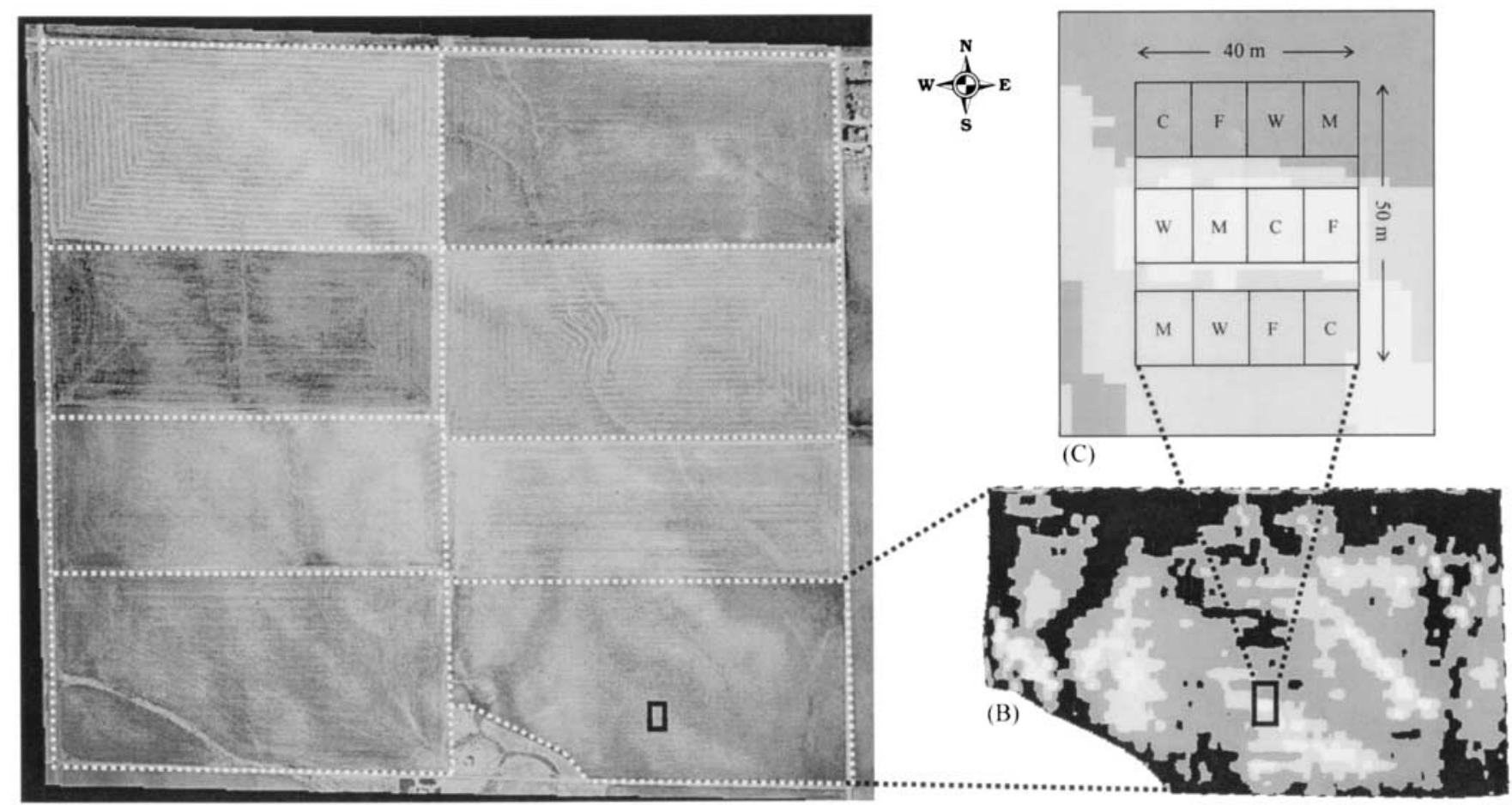

(A)

Fig. 3. Relationship between apparent electrical conductivity $\left(\mathbf{E C}_{\mathrm{a}}\right)$ classification and plot-scale blocking (replication). (A) An aerial photograph of the experimental site with an example of a plot-scale experiment in the center of the southeast field, $(B)$ an $\mathrm{EC}_{\mathrm{a}}$-classified map of the field, and (C) the plot-scale experimental site identified within the field using $\mathrm{EC}_{\mathrm{a}}$ classification as a basis for blocking. 
that only data from the wheat-fallow treatment were used. This treatment most closely resembled FICS residue measurements taken the first year following conversion from wheatfallow management. Bulk density measurements in the SDAMP were collected from randomly selected points within the three slope aspects at a different time than other soil tests. For each soil parameter, equality of MS errors from the FICS and SDAMP were tested at the $P=0.05$ level of significance. All statistical analyses were conducted using SAS (SAS Inst., Cary, NC).

\section{RESULTS AND DISCUSSION}

\section{Within-Field Mean Square Error for Estimating Field-Scale Experimental Error}

By comparing the within-field MS errors for several soil parameters with those derived from replication, we were able to evaluate the use of within-field variance as a surrogate for traditional experimental error. Some surface soil properties, including laboratory-measured EC, $\mathrm{NO}_{3}-\mathrm{N}, \mathrm{NH}_{4}-\mathrm{N}, \mathrm{pH}$, extractable $\mathrm{P}$, and microbial biomass $\mathrm{C}$, did not have significantly larger MS (rep $\times$ crop) than MS (within field) (Table 4), indicating that within-field variance was an adequate measure of experimental error for these parameters. However, the MS (within field) was smaller than MS (rep $\times$ crop) for other properties, including total and particulate $\mathrm{OM}$ (0.05- to 0.5 - and 0.5 - to $2-\mathrm{mm}$ size fractions), total $\mathrm{C}$ and $\mathrm{N}$, microbial biomass $\mathrm{N}$, potentially mineralizable $\mathrm{N}$, and all soil physical parameters, including bulk density; percentage sand, silt, and clay; and gravimetric water content. This variability is consistent with surface soil exposure to wide variations in precipitation, crop biomass (organic $\mathrm{C}$ and $\mathrm{N}$ ), fertilizer inputs, and erosion losses. There was no significant additivity, so the above MS (rep $\times$ crop) did not appear to be exaggerated.

Fewer deep-sample (0-30 cm) soil attributes had MS's (within field) that were smaller than MS (rep $\times$ crop) (Table 5). Only bulk density, $\mathrm{NO}_{3}-\mathrm{N}, \mathrm{NH}_{4}-\mathrm{N}$, total and particulate $\mathrm{OM}$, and microbial biomass $\mathrm{N}$ fell into this category. Nonadditivity was not significant, thereby confirming these results.

It is clear from our analyses that within-field error can sometimes be used as a surrogate for experimental error derived from replication. This must be verified for specific locations. Ideally, information from previous experiments can be used to determine whether withinfield error provides an adequate estimate of experimental error. However, in cases where no prior information is available, a preliminary year of evaluation should be undertaken that includes replication to allow comparison between MS (within field) and MS (rep $\times$ crop). Specific soil attributes should be evaluated within the context of experimental objectives. For example, a research goal for the FICS site is to evaluate temporal trends in soil condition associated with management; thus, it may not be wise to eliminate replication because within-field variability did not provide an accurate estimate of experimental error for surface soil C. Yet, it may be possible to adequately assess research goals related to deeper soil characteristics without using repli- cation at this site, assuming that the site and the way it is treated are representative of other fields to which statements will be applied.

In situations where the elimination of replication is proven appropriate, an additional treatment(s) could be added to the experiment. For example, the FICS site (Fig. 1) could be split from north to south into two treatment areas. Different tillage regimes could then be assigned to the east and west sides of the study site and compared over time for their impact on soil parameters and yield. Data could be analyzed as a complete block, with $\mathrm{EC}_{\mathrm{a}}$ classes functioning as replicates. Given this scenario, it is important to note that tillage treatments would be confounded with fields, so conclusions regarding treatment differences would be based on the assumption that each field is representative of the population of fields of interest.

\section{Estimating Plot-Scale Experimental Error from Field-Scale Experiments}

Within-field $\mathrm{EC}_{\mathrm{a}}$ classification of soil condition presents interesting possibilities for agronomic field designs. Soil condition has been defined as the combination of soil characteristics that establish the level of soil function as a medium for crop production and a contributor to air and water quality (Johnson et al., 2001). For the FICS site, classification based on $\mathrm{EC}_{\mathrm{a}}$ delineates distinct zones of soil condition that are related to yield variability within a uniformly managed field (Johnson et al., 2001, 2003). Therefore, $\mathrm{EC}_{\mathrm{a}}$ classification can be used as a basis for blocking to control experimental-error variance where classes function as experimental blocks. Blocking by $\mathrm{EC}_{\mathrm{a}}$ class is appropriate because classes are related to outcome (yield) differences expected in the absence of treatments (the rationale for blocking).

The disparity in scale between a typical plot-scale experiment and the section of farmland (250 ha) comprising the FICS site is illustrated in Fig. 3. The image on the left $(\mathrm{A})$ is an aerial photograph of the site with an example of a plot-scale experiment shown as a black square near the center of the southeast field. An $\mathrm{EC}_{\mathrm{a}}$ map of this same field, classified into four conductivity ranges, is shown on the lower right (B). The selected plot-scale site encompasses three of the four conductivity classes, likely providing an excellent basis for blocking. Although this is shown as a traditional layout (C), because the blocks ( $\mathrm{EC}_{\mathrm{a}}$ classes) are homogeneous, there is no reason that they must be adjacent to one another. Plots could be scattered throughout the field, randomly applied to all four $\mathrm{EC}_{\mathrm{a}}$ classes. It is now a small step to conceptualize the entire experimental site as an enlarged rendition of the pictured plot-scale experiment where variability within $\mathrm{EC}_{\mathrm{a}}$ class represents the experimental error of the plot-scale experiment.

The presence of the plot-scale SDAMP, within close proximity and comprised of the same soil types found in the FICS, provided an opportunity for testing these relationships between plot-scale experimental error and the variance of field-scale $\mathrm{EC}_{\mathrm{a}}$ classified within-field 
JOHNSON ET AL.: DESIGNING FIELD-SCALE RESEARCH

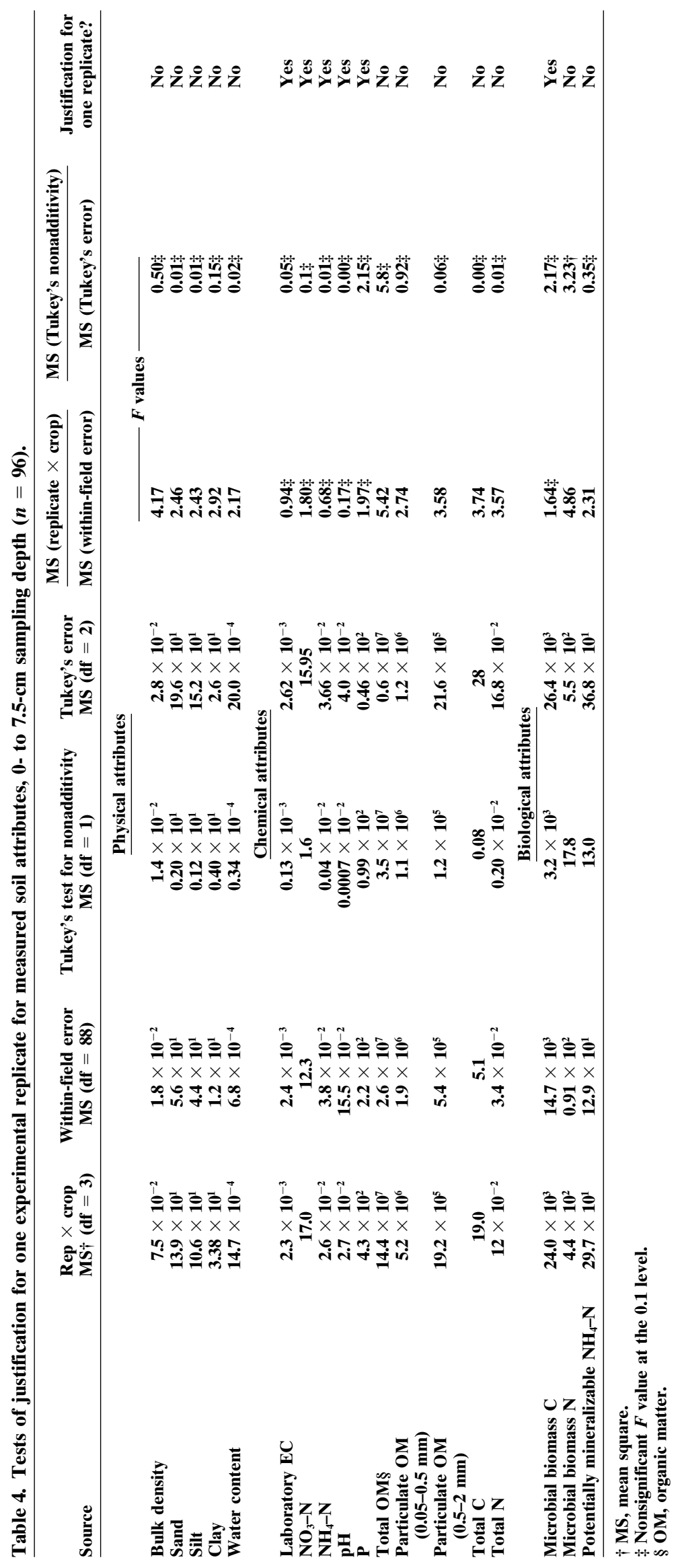




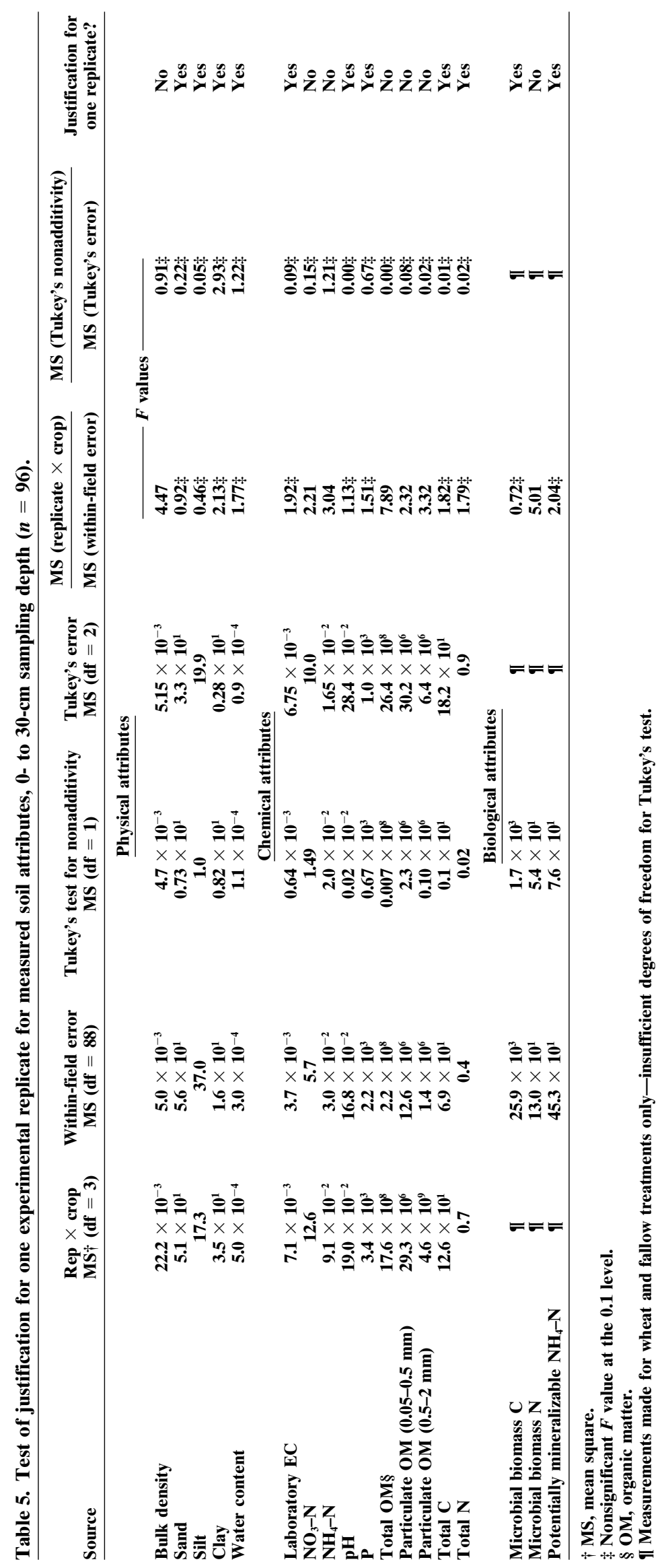


Table 6. Comparison of field- and plot-scale soil attribute and surface residue means [within apparent electrical conductivity $\left(\mathrm{EC}_{\mathrm{a}}\right)$ classes or slope position] and mean square errors (MSEs) from the Farm-Scale Intensive Cropping Study (FICS) and the Sustainable Dryland Agroecosystem Management Project (SDAMP).

\begin{tabular}{|c|c|c|c|c|c|c|c|c|c|c|}
\hline \multirow[b]{3}{*}{ Soil attribute } & \multirow[b]{3}{*}{ Units } & \multicolumn{5}{|c|}{ FICS field scale } & \multicolumn{4}{|c|}{ SDAMP plot scale } \\
\hline & & \multicolumn{4}{|c|}{ Soil attribute means by $\mathrm{EC}_{\mathrm{a}}$ class } & \multirow{2}{*}{$\begin{array}{c}\text { MS } \dagger \\
\text { within } \\
\text { EC }_{\mathrm{a}} \text { class }\end{array}$} & \multicolumn{3}{|c|}{ Soil attribute by slope } & \multirow[b]{2}{*}{ MSE } \\
\hline & & Low & Med. low & Med. high & High & & Toeslope & Sideslope & Summit & \\
\hline & & & & & & 0-7.5 cm de & & & & \\
\hline Total C $\div$ & $\operatorname{Mg~ha}^{-1}$ & 13.4 & 11.3 & 9.5 & 9.2 & 2.2 & 9.6 & 9.4 & 8.4 & 2.6 \\
\hline Total N & Mg ha ${ }^{-1}$ & 1.20 & 1.04 & 0.91 & 0.87 & 0.016 & 0.82 & 0.86 & 0.79 & 0.010 \\
\hline pH & & 6.22 & 6.21 & 6.38 & 6.51 & 0.14 & 7.44 & 7.33 & 6.88 & 0.09 \\
\hline $\mathbf{P}$ & $\mathbf{k g ~ h \mathbf { h a } ^ { - 1 }}$ & 41.9 & 29.8 & 15.7 & 13.0 & 58 & 19.9 & 18.7 & 16.8 & 28 \\
\hline \multirow[t]{2}{*}{ Bulk density } & $\mathrm{g} \mathrm{cm}^{-3}$ & 1.38 & 1.47 & 1.51 & 1.56 & 0.013 & 1.20 & 1.29 & 1.36 & $0.003 *$ \\
\hline & & \multicolumn{9}{|c|}{ 0-30 cm depth } \\
\hline Total C & $\operatorname{Mg~ha}^{-1}$ & 43.8 & 35.2 & 32.2 & 32.7 & 45.5 & 37.4 & 33.5 & 35.8 & $11.2 *$ \\
\hline Total N & $\operatorname{Mg~ha}{ }^{-1}$ & 4.08 & 3.45 & 3.09 & 3.10 & 0.22 & 3.53 & 3.42 & 3.96 & $0.05^{*}$ \\
\hline pH & & 6.33 & 6.42 & 6.72 & 6.92 & 0.12 & 7.63 & 7.64 & 7.13 & 0.08 \\
\hline $\mathbf{P}$ & $\mathbf{k g ~ h a} \mathbf{h}^{-1}$ & 111.8 & 69.2 & 27.8 & 26.7 & 752 & 53.5 & 36.3 & 41.8 & $255^{*}$ \\
\hline \multirow[t]{2}{*}{ Bulk density } & $\mathrm{g} \mathrm{cm}^{-3}$ & 1.32 & 1.39 & 1.39 & 1.42 & 0.0036 & 1.33 & 1.33 & 1.42 & $0.0005^{*}$ \\
\hline & & \multicolumn{9}{|c|}{ Surface } \\
\hline Residue (preplant) & $\mathbf{k g ~ h a}^{-1}$ & 2802 & 1583 & 1677 & 875 & $8.6 \overline{10^{5}}$ & 4477 & 2269 & 2564 & $19.5 \times 10^{5}$ \\
\hline Residue (harvest) & $\mathbf{k g ~ h a}^{-1}$ & 5164 & 3504 & 2881 & 2118 & $9.6 \times 10^{5}$ & 5334 & 4200 & 4002 & $30.5 \times 10^{5 *}$ \\
\hline
\end{tabular}

* Field-scale mean square within $\mathrm{EC}_{\mathrm{a}}$ class and plot-scale mean square errors are significantly different at the 0.05 level.

$\dagger$ MS, mean square.

† The number of degrees of freedom for each variable was 64/18 (field scale/plot scale) except for bulk density (64/15), preplant residue (16/84), and postharvest residue (16/44).

variability. Comparisons between soil and residue analyses made from the two sites are shown in Table 6. For surface soil $\left(0-7.5 \mathrm{~cm}\right.$ depth), the MS within $\mathrm{EC}_{\mathrm{a}}$ class errors for surface soil did not differ from MS error for the plot-scale experiment for any measured parameters except bulk density $(P \geq 0.05)$. At the 0 - to 30 -cm depth, only MS for $\mathrm{pH}$ was the same for plot-scale error and within $\mathrm{EC}_{\mathrm{a}}$ class field-scale analyses. However, while plot- and field-scale MS's for C and N and extractable $\mathrm{P}$ were significantly different, they showed only threeto fourfold differences. This degree of heterogeneity is not excessive because it has little effect on ANOVA (Scheffe, 1959).

As in surface soil analyses, differences in calculated MS from the two study sites, at the $0-$ to $30-\mathrm{cm}$ depth, were greatest for bulk density. This is not surprising for two reasons. First, SDAMP bulk density measurements were taken in 1989, $3 \mathrm{yr}$ after the initiation of no-tillage management, whereas the FICS measurements were taken during the first year of no-tillage. Because tillage is known to significantly impact bulk density, its recent employment in the FICS may have increased bulk density variance. In addition, bulk density affects the volumetric expression of $\mathrm{P}$ and total $\mathrm{C}$ and $\mathrm{N}$, an effect that is magnified with increasing soil depth. It is possible that the variances of the FICS soil analyses, particularly at the $0-$ to $30-\mathrm{cm}$ depth, were inflated and will more closely resemble those of the SDAMP over time. Second, because SDAMP bulk density measurements were taken independently of other parameters, mean bulk density values within each slope variable were used to convert $\mathrm{P}$ and total $\mathrm{C}$ and $\mathrm{N}$ to volumetric basis. This approach likely reduced parameter variances relative to that used in the FICS.

Although preplant residue MS did not differ $(P \leq$ 0.05 ) between the SDAMP and FICS sites, the magnitude of residue levels was greater for SDAMP than
FICS (Table 6). Data from SDAMP were collected from wheat-fallow treatments only (the best basis for comparison) over a period of $12 \mathrm{yr}$. Because this treatment was managed using no-till, these data reflected residue accumulation not found during the first year of the FICS experiment. Postharvest residue measurements had threefold greater variance at the plot scale than at the farm scale. This may also reflect differences in experiment age at the time of residue collection. Residue levels at the SDAMP site resulted from multiple-year accumulations that have been exposed to varying rates of decomposition and wind and water erosion, factors increasing variability in surface residue cover and biomass production. It is difficult to make clear-cut comparisons of measurements from two different experimental sites. Yet, even though MS differences were likely falsely elevated due to different sampling times relative to the age of each experiment, MS compared well among the two studies (two levels of scale).

\section{CONCLUSIONS}

Many deep $(0-30 \mathrm{~cm})$ and shallow $(0-7.5 \mathrm{~cm})$ soil indices evaluated at the FICS site-broadly selected to appraise soil physical, chemical, and biological characteristics within fields-showed no difference between standard errors derived from replication and those educed from within-field variability. Thus, for some research objectives, it may be possible to use within-field error as a reasonable estimate of experimental error, eliminating the need for treatment replication. This assumes that each experimental field is representative of the population of fields of interest. A need for only one experimental unit per treatment may provide space, and therefore opportunity, for additional treatment(s). This applies to the assessment of within-field variability through traditional random sampling or $\mathrm{EC}_{\mathrm{a}}$-classified 
sampling. Further research is needed to determine the degree to which these results are transferable to other soils and locations. Relationships between MS (rep $\times$ crop) and MS (within field) must be verified for specific soil properties, at specific sites to which they may be applied, before eliminating replication.

Classified maps based on $\mathrm{EC}_{\mathrm{a}}$ can sometimes be used to delineate soil spatial heterogeneity at large experimental scales. At the FICS site, $\mathrm{EC}_{\mathrm{a}}$-classified withinfield variability was similar to MS error at the nearby SDAMP plot-scale experiment, indicating that fieldscale MS (within field) variability is synonymous with soil heterogeneity partitioned by blocking at the plotscale. Within-field $\mathrm{EC}_{\mathrm{a}}$ classes do not constitute traditional blocks, defined as sets of homogeneous experimental units. In our experimental design, each field to which a treatment (crop) was applied represents one experimental unit. Instead of comprising a set of experimental units unto themselves, the four $\mathrm{EC}_{\mathrm{a}}$ classes assigned to each treatment fall within one experimental unit, i.e. within-field blocking.

The relationship between experimental error derived from $\mathrm{EC}_{\mathrm{a}}$-classified zones and plot-scale blocking supports an alternative in experimental design. Hargrove and Pickering (1992) suggested using nonreplicated large-scale experiments to develop hypotheses; these hypotheses could then be applied to smaller-scale experiments from which large-scale processes could be inferred. Within-field variability, delineated by $\mathrm{EC}_{\mathrm{a}}$ classification, may facilitate such an approach. We propose using $\mathrm{EC}_{\mathrm{a}}$-classified MS (within field) in field-scale experiments to estimate plot-scale experimental error. Treatment differences and their standard errors could then be used in a systems approach to roughly evaluate treatments and identify research questions requiring further study in plot-scale experiments.

Research conducted on farm at the field scale can improve the accountability of agronomic research to the producers it serves. Incorporating unclassified and $\mathrm{EC}_{\mathrm{a}}$-classified within-field variability in the design of field-scale experiments may advance on-farm research by offering alternative methods for statistical analyses.

\section{ACKNOWLEDGMENTS}

We gratefully acknowledge Russ and Matt Johnson, landowners and managers of the experimental site. We appreciate the expertise of Prabhakar Dhungana, Lucretia Sherrod, Timothy Kettler, Michael Schlemmer, Aaron Schepers, and Hamid Farahani and the technical assistance of Tara Gilbert, John Bricker, Susan Wagner, Spencer Arnold, Igor Coelho, Bob Florian, and Gene Uhler.

\section{REFERENCES}

Beyers, D.W. 1998. Causal inference in environmental impact studies. J. N. Am. Benthological Soc. 17:367-373.

Blake, G.R., and K.H. Hartge. 1986. Bulk density. p. 363-375. In A. Klute (ed.) Methods of soil analysis. Part 1.2nd ed. Agron. Monogr. 9. ASA and SSSA, Madison WI.

Bowman, R.A., M.F. Vigil, D.C. Nielsen, and R.L. Anderson. 1998. Soil organic matter changes in intensively cropped dryland systems. Soil Sci. Soc. Am. J. 63:186-191.
Box, G.E.P., W.G. Hunter, and J.S. Hunter. 1978. Statistics for experimenters. John Wiley \& Sons, New York.

Bray, R.H., and L.T. Kurtz. 1945. Determination of total, organic, and available forms of phosphorus in soils. Soil Sci. 59:39-45.

Cambardella, C.A., J.W. Doran, and A. Gajda. 2000. A simplified procedure for particulate organic matter by weight loss on ignition. p. 349-359. In R. Lal, J.M. Kimble, R.F. Follett, and B.A. Steward (ed.) Methods of assessment of soil carbon. CRC Press, Boca Raton, FL.

Carpenter, S.R. 1990. Large-scale perturbations: Opportunities for innovation. Ecology 7(6):2038-2043.

Doran, J.W., and T.B. Parkin. 1996. Quantitative indicators of soil quality: A minimum data set. p. 25-38. In J.W. Doran and A.J. Jones (ed.) Methods for assessing soil quality. SSSA Spec. Publ. 49. SSSA, Madison, WI.

ERDAS. 1997 ERDAS field guide. p. 225-232. ERDAS, Atlanta, GA. Gerber, J.M. 1992. Farmer participation in research: A model for adaptive research and education. Am. J. Altern. Agric. 7:118-121.

Hannah, M.C. 1999. Usefully combining a series of unreplicated cheesemaking experiments. J. Dairy Res. 66:365-374.

Hargrove, W.W., and J. Pickering. 1992. Pseudoreplication: A sine qua non for regional ecology. Landscape Ecol. 6:251-258.

Hawkins, C.P. 1986. Pseudo-understanding of pseudoreplication: A cautionary note. Bull. Ecol. Soc. Am. 67(2):184-185.

Ikerd, J.E. 1993. The question of good science. Am. J. Altern. Agric. 8(2):91-92.

Islam, K.R., R.R. Weil, and C.L. Mulchi. 1998. Microwave irradiation of soil for routine measurement of microbial biomass carbon. Biol. Fertil. Soils 27:408-416.

Jaynes, D.B., T.S. Colvin, and J. Ambuel. 1993. Soil type and crop yield determinations from ground conductivity surveys. ASAE Paper 933552. ASAE, St. Joseph, MI.

Johnson, C.K., J.W. Doran, H.R. Duke. B.J. Wienhold, K.M. Eskridge, and J.F. Shanahan. 2001. Field-scale electrical conductivity mapping for delineating soil condition. Soil Sci. Soc. Am. J. 65: 1829-1837.

Johnson, C.K., D.A. Mortensen, B.J. Wienhold, J.F. Shanahan, and J.W. Doran. 2003. Site-specific management zones based on soil electrical conductivity in a semiarid cropping system. Agron. J. 95:303-315.

Johnson, J.J., J.R. Alldredge, S.E. Ullrich, and O. Dangi. 1992. Replacement of replications with additional locations for grain sorghum cultivar evaluation. Crop Sci. 32:43-46.

Keeney, D.R. 1982. Recommended biological index-ammoniumnitrogen production under waterlogged conditions. p. 727-728. In A.L. Page, R.H. Miller, and D.R. Keeney (ed.) Methods of soil analysis. Part 2. 2nd ed. Agron. Monogr. 9. ASA and SSSA, Madison, WI.

Kettler, T.A., J.W. Doran, and T.L. Gilbert. 2001. A simplified method for soil particle size determination to accompany soil quality analyses. Soil Sci. Soc. Am. J. 65:849-852.

Khakural, B.R., P.C. Roberts, and D.R. Hugins. 1998. Use of noncontacting electromagnetic inductive methods for estimating soil moisture across a landscape. Commun. Soil Sci. Plant Anal. 29: 2055-2065.

Kitchen, N.R., K.A. Sudduth, and S.T. Drummond. 1999. Soil electrical conductivity as a crop productivity measure for claypan soils. J. Prod. Agric. 12:607-617.

Lentner, M., and T. Bishop. 1993. Experimental design and analysis. Valley Book Co., Blacksbury, VA.

Lesch, S.M., J.D. Rhoades, L.J. Lund, and D.L. Corwin. 1992. Mapping soil salinity using calibrated electromagnetic measurements. Soil Sci. Soc. Am. J. 56:540-548.

Lockeretz, W. 1987. Establishing the proper role for on-farm research. Am. J. Altern. Agric. 2:132-136.

Lund, E.D., D. Christy, and P.E. Drummond. 1999. Applying soil electrical conductivity technology to precision agriculture. p. 10891100. In P.C. Robert et al. (ed.) Precision agriculture. Proc. Int. Conf., 4th, St. Paul, MN. 19-22 July 1998. ASA, CSSA, and SSSA, Madison, WI.

McNeill, J.D. 1980. Electrical conductivity of soils and rocks. Tech. Note TN-5. Geonics Limited, Mississauga, ON, Canada.

Moreau, L., H. Monod, A. Charcosset, and A. Gallais. 1999. Marker- 
assisted selection with spatial analysis of unreplicated field trials. Theor. Appl. Genet. 98:234-242.

Norman, D.W., L.E. Bloomquist, S.G. Freyenberger, D.L. Regehr, B.W. Schurle, and R.R. Janke. 1998. Farmers attitudes concerning on-farm research: Kansas survey results. J. Nat. Resour. Life Sci. Educ. 27:35-41.

Norman, D., F. Worman, J. Siebert, and E. Modiakgotla. 1995. The farming systems approach to development and appropriate technology generation. FAO Farm Syst. Manage. Ser. 10. Agric. Serv. Div., Food and Agric. Organ. of the United Nations, Rome.

Olsen, S.R., and L.A. Dean. 1965. Phosphorus. p. 1035-1049. In C.A. Black et al. (ed.) Methods of soil chemical analysis. Part 2. Agron. Monogr. 9. ASA, Madison, WI.

Peterson, G.A., A.D. Halvorson, J.L. Havlin, O.R. Jones, D.J. Lyon, and D.L. Tanaka. 1998. Reduced tillage and increasing cropping intensity in the Great Plains conserves soil C. Soil Tillage Res. 47:207-218.

Peterson, G.A., A.J. Schlegel, D.L. Tanaka, and O.R. Jones. 1996. Precipitation use efficiency as affected by cropping and tillage systems. J. Prod. Agric. 9:180-186.

Peterson, G.A., D.G. Westfall, and C.V. Cole. 1993. Agroecosystem approach to soil and crop management research. Soil Sci. Soc. Am. J. 57:1354-1360.

Rhoades, J.D., and D.L. Corwin. 1981. Determining soil electrical conductivity-depth relations using an inductive electromagnetic soil conductivity meter. Soil Sci. Soc. Am. J. 45:2552-2560.

Rhoades, J.D., N.A. Manteghi, P.J. Shouse, and W.J. Alves. 1989. Soil electrical conductivity and soil salinity: New formulations and calibrations. Soil Sci. Soc. Am. J. 53:433-439.

Rzewnicki, P. 1991. Farmer's perceptions of experiment station research, demonstrations, and on-farm research in agronomy. J. Agron. Educ. 20:31-36.

Sahagün-Castellanos, J., and K.J. Frey. 1994. Efficiencies of three procedures for evaluation of oat (Avena sativa L.) experimental lines in unreplicated experiments. J. Genet. Breed. 48:405-414.

Scheffe, H. 1959. The analysis of variance. Wiley, New York.

Sheets, K.R., and J.M.H. Hendrickx. 1995. Noninvasive soil water content measurement using electromagentic induction. Water Res. 31:2401-2409.

Stewart-Oaten, A., J.R. Bence, and C.W. Osenberg. 1992. Assessing effects of unreplicated perturbations: No simple solutions. Ecology 73:1396-1404.

Stewart-Oaten, A., W.W. Murdock, and K.R. Parker. 1986. Environmental impact assessment: "Pseudoreplication" in time? Ecology 67:929-940.

Sudduth, K.A., S.T. Drummond, and N.R. Kitchen. 2001. Accuracy issues in electromagnetic induction sensing of soil electrical conductivity for precision agriculture. Comput. Electron. Agric. 31:239264.

Sudduth, K.A., D.F. Hughes, and S.T. Drummond. 1995. Electromagnetic induction sensing as an indicator of productivity on claypan soils. p. 671-681. In P.C. Robert, R.H. Rust, and W.E. Larson (ed.) Site-specific management for agricultural systems. Proc. Int. Conf., 2nd, Minneapolis, MN. 27-30 Mar. 1994. ASA, CSSA, and SSSA, Madison, WI.

Sumberg, J., and C. Okali. 1988. Farmers, on-farm research and the development of new technology. Exp. Agric. 24:333-342.

Tukey, J.W. 1949. One degree of freedom for non-additivity. Biometrics 5:232-242.

Vanden Heuvel, R.M. 1996. The promise of precision agriculture. J. Soil Water Conserv. 51(1):38-40.

Waring, S.A., and J.M. Bremmer. 1964. Ammonium production in soil under waterlogged conditions as an index on nitrogen availability. Nature 201:951-952.

Watkins, G. 1990. Participatory research: A farmer's perspective. Am. J. Altern. Agric. 5:161-162.

Wiens, J.A., and K.R. Parker. 1995. Analyzing the effects of accidental environmental impacts: Approaches and assumptions. Ecol. Applic. 5:1069-1083. 